\title{
Analisis Keterlaksanaan Pembelajaran Penjaskes Di Smpn Sekecamatan Bayan Kabupaten Lombok Utara Tahun Pengajaran 2021
}

\author{
Intan Kusuma Wardan \\ Dosen Pendidikan Olahraga dan Kesehatan, FIKKM UNDIKMA \\ Email: intakusumawardani7@gmail.com
}

\begin{abstract}
Abstrak. Berdasarkan hasil survei dan observasi di lapangan bahwa ada beberapa sekolah yang masih belum maksimal dalam pengajaran pembelajaran pendidikan jasmani olahraga dan kesehatan diantaranya sekolah SMPN sekecamatan bayan, dikarenakan guru pengampu yang mengajar bukan guru pendidikan jasmani olahraga dan kesehatan, tetapi lebih menggunakan guru umum atau yang megajar di berbagai mata pelajaran Dengan keadaan yang seperti itu, maka dari itu peneliti tertarik melakukan penelitian tentang pelaksanaan pembelajaran pendidikan jasmani olahraga dan kesehatan di SMPN Se-Kecamatan Bayan Kabupaten Lombok Utara. Berdasarkan uraian pada latar belakang masalah di atas, maka peneliti merumuskan masalah yang akan diteliti adalah bagaimanakah keterlaksanaan pembelajaran PENJASKES di SMPN SeKecamatan Bayan Kabupaten Lombok Utara Tahun Pengajaran 2020/2021. Berdasarkan rumusan masalah tersebut, maka tujuan yang ingin dicapai dalam penelitian ini adalah untuk mengetahui bagaimana keterlaksanaan pembelajaran PENJASKES di SMP Kecamatan Bayan Kabupaten Lombok Utara Tahun Pelajaran 2020/2021. Rancangan penelitian yang digunakan dalam penelitian ini adalah pendekatan kualitatif yang berupa kata kata. Data yang diperoleh dalam penelitian ini lebih banyak berupa kata- kata yang bersifat kualitatif dari pada data dalam wujud angka-angka.. Instrumen yang digunakan dalam penelitian ini adalah peneliti itu sendiri dibantu dengan pedoman wawancara dan lembar pengamatan. Teknik pengumpulan data yang digunakan dalam penelitian ini adalah wawancara,pengamatan dan dokumentasi. Pemahaman para guru penjaskes khususnya pada kasus keterlakasanaan pembelajaran penjaskes masuk dalam kategori baik dengan persentase 66\% 3 guru penjas dari keseluruhan pelatih (12 guru) yang diambil sebagai sampel, $12 \%$ (12 guru) masuk dalam kategori cukup baik.
\end{abstract}

Kata Kunci : Guru Penjaskes.Keterlaksanaan pembelajaran penjaskes

\section{PENDAHULUAN}

Pendidikan Jasmani Olahraga dan Kesehatan merupkan proses pendidikan yang memberikan perhatian kepada aktivitas pengembnagan jasmani manusia. Pendidikan jasmani, Olahraga, dan kesehatan merupakan proses pendidikan yang memanfaatkan aktivitas fisik jasmani dan olahraga untuk menghasilkan perubahan holistic dalam kualitas individu, Baik dalam hak fisik, mental, serta emosional (Hartono. dkk, 2013: 2).

Pendidikan jasmani, Olahraga, dan kesehatan merupakan wahana pendidikan yang memberikan kesempatan bagi anak untuk mempelajari hal-halyang penting. Oleh karena itu pelajaran PENJASKES tidak kalah penting dibandingkan pelajaran lainnya, seperti Matematika, Bahasa, IPS dan IPA, dan lain-lain (Hudarta , $2011:$ 18).

Pendidikan Jasmani di Indonesia hingga saat ini belum efektif dan efisien dalam pembelajaran di sekolah. Melihat kondisi yang memperhatikan dapat memberikan dampak kepada perkembangan siswa dalam menunjang kompetensi dan hasil belajar dari siswa. Faktor yang menyebabkan terbatasnya dan tidak berkembangnya kemampuan siswa ialah metode pembelajaran yang dilakukan oleh guru terlalu menoton, seorang guru tidak mengenal karakter siswa sebelum memberikan materi ajar, seorang guru tidak menguasai materi ajar, guru pendidikan jasmani tidak sesuai dengan bidang keilmuannya.

Hal ini dibenarkan oleh (Taqwim et al, 2020) dalam pelaksanaan pembelajaran guru masih jarang melakukan kegiatan evaluasi pembelajaran pada saat penutupan yang dialihkan menjadi waktu pergantian seragam menuju tahap persiapan mengikuti kegiatan pembelajaran selanjutnya dan tidak adanya kegiatan pendinginan yang dilakukan oleh seorang guru pendidikan jasmani dan olahraga kepada siswa. Sedangkan kita ketahui bahwa pendidikan jasmani merupakan pendidikan yang 
terintegral yang dapat meningkatkan emosional, kebugaran jasmani, sosial, spiritual, sportifitas, fisik, dan psikis peserta didik. Maka dalam pelaksanaan pembelajaran pendidikan jasmani guru hendaknya benar-benar mempersiapkan secara matang dalam menujang keberhasilan pembelajaran secara menyeluruh.

Di kalangan masyarakat, masih banyak orang yang keliru mengenai guru pembelajaran pendidikan jasmani olahraga dan kesehatan. Guru pembelajaran pendidikan jasmani olahraga dan kesehatan dianggap sebagai pekerjaan yang mudah. Bagi mereka pekerjaan guru pembelajaran pendidikan jasmani olahraga dan kesehatan adalah membiarkan anak bermain bola dan memperhatikannya dari tepi lapangan.

Fenomena itulah yang melatarbelakangi penulis untuk membahas guru profesional, khususnya guru pembelajaran pendidikan jasmani olahraga dan kesehatan. Untuk dapat melaksanakan tugasnya sebagai guru pembelajaran pendidikan jasmani olahraga dan kesehatan dengan baik, maka sebaiknya mereka mengetahui dengan persis kemampuan apa saja yang harus dikuasai. Seperti yang telah diuraikan di atas bahwa banyak nilai-nilai yang perlu ditanamkan dalam diri siswa. Agar nilai tersebut dapat tercapai, proses pelaksanaan pembelajaran pendidikan jasmani olahraga dan kesehatan perlu lebih diperhatikan dan dilakukan pemantauan terkait efisiensi dan efektifitas. Hal tersebut dirasa perlu dilakukan karena pelaksanaan pembelajaran pendidikan jasmani olahraga dan kesehatan tidak hanya aktivitas fisik biasa dan bermain semata, karena memang sesunggunya pembelajaran pendidikan jasmani olahraga dan kesehatan adalah suatu aktivitas yang terencana dan memiliki tujuan yang jelas. Atau dengan kata lain pembelajaran pendidikan jasmani olahraga dan kesehatan dilaksanakan sedemikian rupa sehingga dapat mengarah dan mencapai manfaat yang dicita-citakan oleh siswa.

Berdasarkan hasil observasi yang dilakukan peneliti, terdapat beberapa sekolah yang belum maksimal dalam pelaksanaan pembelajaran pendidikan jasmani olahraga dan kesehatan. Di antara sekolah SMPN SeKecamatan Bayan Kabupaten Lombok Utara. Dalam pelaksanaan pembelajaran pendidikan jasmani olahraga dan kesehatan, guru-guru disana memiliki caranya tersendiri, yaitu dengan melaksanakan kegiatan pembelajaran secara serempak satu kali dalam seminggu dengan guru pengampu dan guru kelas masing-masing. Pembelajaran pendidikan jasmani olahraga dan kesehatan yang diampu oleh guru kelas juga terdapat kendala dalam pelaksanaanya. Kendala itu dapat timbul dari beberapa faktor yang berpengaruh pada tidak maksimalnya pelaksanaan pembelajaran pendidikan jasmani olahraga dan kesehatan. Dengan keadaan yang seperti itu, maka dari itu peneliti bermaksud mendeskripsikan bagaimana proses pelaksanaan pembelajaran pendidikan jasmani olahraga dan kesehatan di SMPN Se-Kecamatan Bayan Kabupaten Lombok Utara.

Sekolah SMP se-kecamatan bayan kabupaten lombok utara memunculkan kesadaran akan pentingnya guru penjaskes yang profesional demi terwujudnya pendidikan yang bermutu. Dengan memiliki guru pendidikan pembelajaran pendidikan jasmani olahraga dan kesehatan yang profesional maka mestinya pelajaran yang disampaikan akan lebih tepat karena pengampunya lebih menguasai tentang materi, tahapan pembelajaran, indikator keberhasilan serta faktor-faktor lain yang merupakan esensi dari pembelajaran pendidikan jasmani olahraga dan kesehatan.

\section{KAJIAN PUSTAKA}

\section{Hakikat Pembelajaran}

Dunia pendidikan tidak akan pernah terlepas proses pembelajaran. Pembelajaran dengan kata dasar belajar sebenarnya merupakan proses yang mencakup dua hal yaitu belajar itu sendiri dan mengajar. Kegiatan belajar biasanya difukoskan pada kegiatan siswa dalam pendidikan. Sedangkan mengajar biasanya difokuskan pada kegiatan guru dalam pembelajaran. Meski dewasa ini, kegiatan belajar dan mengajar dapat dilakukan oleh semua pelaku pendidikan tidak hanya guru dan siswa.

Pembelajaran yang mencakup kedua hal diatas diartikan oleh Menurut Wahit, dkk (2012: 79) sebagai sebuah interaksi mengajar dan belajar sebagai proses saling mempengaruhi. Lebih lanjut, Wahit dkk (2012: 254) mendefinisikan pelaksanaan 
pembelajaran sebagai situasi dimana setiap pelajar atau guru harus bisa membuat strategi pengajaran dan menyediakan kesempatan kepada siswa untuk melakukan kegiatan belajar secara aktif dan professional.

Dimayati dan Mudjiono (Syaiful: 2006) mengartikan pembelajaran sebagai kegiatan guru secara terprogram dalam desain instruksional dengan tujuan agar siswa belajar secara aktif, yang menekankan kepada penyediaan sumber belajar. Pendapat yang dikemukakan di atas secara tidak langsung mengartikan pembelajaran sebagai fasilitas yang digunakan oleh guru untuk membuat siswa belajar secara mandiri.

Sedangkan menurut Syaiful Sagala (2006: 64), pembelajaran diartikan sebagai interaksi belajar mengajar yang mengacu pada suatu tujuan tertentu yang telah dirumuskan pada satuan pelajaran atau silabus. Pendapat ini menekankan pada proses yang terjadi dalam pembelajaran yaitu interaksi belajar mengajar. Pendapat ini mendukung pendapatpendapat tokoh sebelumnya yang menyatakan proses dalam pembelajaran terdiri dari 2 hal yaitu belajar dan mengajar.

Berdasarkan beberapa pendapat diatas dapat disimpulkan bahwa pembelajaran mencakup dua hal yaitu belajar dan mengajar sebagai cara untuk memperoleh pengetahuan, keterampilan melalui upaya pendidikan untuk membelajarkan siswa sehingga siswa mengalami perubahan tingkah laku.

2. Pengertian Pendidikan Jasmani Olahraga dan Kesehatan

Pendidikan jasmani, olahraga dan kesehatan (PJOK) merupakan salah satu mata pelajaran wajib di sekolah. Mata pelajaran ini ditujukan untuk menunjang perkembangan psikomotor siswa. Pendidikan jasmani menurut Agus S. Surobroto (2004: 9) merupakan suatu proses pembelajaran yangdidesain untuk meningkatkan kebugaran jasmani, mengembangkan keterampilan motorik, pengetahuan dan perilaku hidup aktif dan sikap sportif melalui kegiatan jasmani. Pada pelaksanaannya pendidikan jasmani mempunyai peran sentral untuk mengarahkan peserta didik dalam rangka menuju keselarasan antara pertumbuhan badan dan perkembangan jiwa. Oleh karena itu, dalam pelaksanaan pendidikan jasmani tidak saja difokuskan pada pertumbuhan fisik semata, tetapi aspek kesehatan jasmani dan rohani, pemupukan watak, sikap, dan intelektual juga menjadi perhatian dalam pendidikan jasmani. Untuk itu diperlukan keselarasan pedoman agar pendidikan jasmani tidak terpisah dari pendidikan total

Menurut Huesdarta dan Yudha M. Saputra (2000: 57) pada dasarnya antara pendidikan jasmani dan olahraga pendidikan adalah sama, sebagai suatu usaha pendidikan dengan menggunakan aktivitas jasmani yang bertujuan untuk meningkatkan kebugaran jasmani dan rohani para siswa yang dilakukan di lembaga sekolah dan dipandu oleh seorang guru dengan acuan kurikulum yang telah ditetapkan. Hanya saja yang membedakan antara pendidikan jasmani dan olahraga pendidikan adalah istilahnya yang beberapa kali diganti atau ditinjau oleh para pakar pendidikan. Dari pengertian pendidikan jasmani di atas, dapat disimpulkan bahwa pendidikan jasmani merupakan bagian dari pendidikan secara umum yang merupakan usaha mengoptimalkan segala potensi yang ada dalam diri anak. Hal tersebut dapat terwujud jika bentuk, isi, dan arah pembelajaran yang dikemas melalui pembinaan dan pengembangan sehingga terwujud peningkatan kualitas manusia seutuhnya.

Pendidikan jasmani juga erat dengan usaha mengoptimalkan segala potensi yang ada dalam diri anak mencakup kegiatan olahraga sebagai permainan yang terartur serta pengajaran kesehatan mengenai pemeliharaan tubuh, pencegahan penyakit, narkotika, dan minuman keras, serta mengatasi stress.

\section{Tujuan Pembelajaran Pendidikan Jasmani Olahraga dan Kesehatan}

Pelaksanaan pembelajaran pendidikan jasmani olahraga dan kesehatan sudah dilakukan dari waktu ke waktu, namun yang menjadi pertanyaan adalah apakah dalam pelaksanaannya itu telah mengacu pada tujuan yang benar atau belum. Dapat dipastikan jika pembelajaran pendidikan jasmani olahraga 
dan kesehatan dilaksanakan tanpa mengacu pada tujuan yang benar, maka pembelajaran pendidikan jasmani olahraga dan kesehatan hanya akan menjadi aktivitas fisik belaka. Tujuan pembelajaran pendidikan jasmani olahraga dan kesehatan menjadi penting karena dalam pelaksanaannya turut membantu guru dalam kesuksesan proses pembelajaran.

Agus Mahendra (2003:6) menyatakan bahwa tujuan pembelajaran pendidikan jasmani olahraga dan kesehatan itu harus mencakup tujuan dalam domain psikomotorik, domain kognitif serta domain afektif.

Berdasakan beberapa pendapat di atas maka dapat ditarik kesimpulan bahwa tujuan pembelajaran pendidikan jasmani olahraga dan kesehatan adalah untuk meningkatkan kebugaran jasmani, mengembangkan keterampilan motorik, pengetahuan dan perilaku hidup sehat dan aktif, sikap sportif, dan kecerdasan emosi. Untuk mencapai tujuan tersebut maka lingkungan pendidikan dirubah sedemikian rupa sehingga dapat meningkatkan perkembangan seluruh ranah, baik itu jasmani, psikomotorik, kognitif, dan afektif setiap siswa.

\section{Pelaksanaan Pembelajaran Pendidikan Jasmani Olahraga dan}

\section{Kesehatan}

Pelaksanaan pembelajaran pendidikan jasmani olahraga dan kesehatan di sekolah dipengaruhi oleh dua faktor utama yaitu kinerja guru pembelajaran pendidikan jasmani olahraga dan kesehatan serta sarana dan prasarana yang memadai. Kinerja guru adalah kemampuan dan usaha guru untuk melaksanakan tugas pembelajaran sebaikbaiknya dalam perencanaan program pengajaran, pelaksanaan kegiatan pembelajaran dan Kinerja guru yang dicapai harus berdasarkan standar kemampuan profesional selama melaksanakan kewajiban sebagai guru di sekolah. Guru menjadi salah satu faktor yang menentukan keberhasilan siswa dalam belajar. Guru juga sangat berperan dalam menentukan keberhasilan proses belajar mengajar, maka dari itu guru dituntut untuk memiliki berbagai kompetensi dasar dalam proses belajar mengajar.
Berkaitan dengan kinerja guru dalam melaksanakan kegiatan belajar mengajar, maka dapat dikemukakan Tugas Keprofesionalan Guru menurut UndangUndang Republik Indonesia Nomor 14 tahun 2005 pasal 20 (a) tentang Guru dan Dosen adalah merencanakan pembelajaran, melaksanakan proses pembelajaran yang bermutu, serta menilai dan mengevaluasi hasil pembelajaran. Kinerja guru yang baik tentunya tergambar pada aspek akademik maupun kemampuan profesi. Menjadi guru artinya mampu mengelola pengajaran dalam kelas dan mendidik siswa di luar kelas dengan sebaik-baiknya.

\section{METODE PENELITIAN}

Dalam melakukan penelitian ini peneliti menggunakan pendekatan kualitatif, ini dapat dilihat dari prosudur yang diterapkan, yaitu prosedur penelitian yang menghasilkan data deskriptif, ucapan atau tulisan dan perilaku yang diamati dari orang-orang (subjek) itu sendiri.

Penelitian ini, penulis arahkan pada Analisis Pelaksanaan Pembelajaran Penjaskes Di SMPN Kecamatan Bayan Kabupaten Lombok Utara Tahun Pelajaran 2020/2021, supaya mendapatkan data deskritif berupa kata-kata tertulis yang disusun berdasarkan data lisan, perbuatan dan dokumentasi yang diamati secara menyeluruh dan apa adanya. Menurut Arikunto "tempat penelitian dapat dilakukan di sekolah, di keluarga, di masyarakat, di publik, di rumah sakit dan sebagainya". Sedangkan penelitian dilakukan di SMP se-Kecamatan Bayan dengan menggunakan pendekatan kualitatatif.

Populasi dari penelitian ini adalah ada 4 sekolah yang nantinya sebagai obyek penelitian di SMPN se-Kecamatan Bayan Kabupaten Lombok Utara Tahun Pelajaran 2020/2021. Menentukan sampel dari populasi yang akan diteliti, peneliti berpijak pada standart Harsimi Arikunto, yaitu apabila subyek atau populasi kurang dari seratus lebih baik diambil semua sehingga penelitiannya merupakan penelitian populasi dan jika subyeknya lebih dari itu maka dapat diambil sampel antara $10-15 \%$ atau $20-$ $25 \%$ atau lebih 38 dari teori tadi, maka dalam penelitian ini mengambil sampel sebesar $10 \%$ sehingga ditemukan sampel sebesar dari jumlah 
keseluruhan populasi adalah guru penelitian di SMPN se-Kecamatan Bayan Kabupaten Lombok Utara Tahun Pelajaran 2020/2021.

Instrumen yang digunakan dalam penelitian ini adalah peneliti itu sendiri dibantu dengan pedoman wawancara dan lembar pengamatan. Pedoman tersebut merupakan pedoman yang dikembangkan peneliti berdasarkan indikator dari masing-masing variabel yang diteliti.

Terkait pengumpulan data tentang pelaksanaan pembelajaran pendidikan jasmani olahraga dan kesehatan di SMP se-Kecamatan Bayan, maka peneliti menggunakan teknik pengumpulan data adalah pengamatan, wawancara, dan dokumentasi.

Data yang diperoleh dalam penelitian ini lebih banyak berupa kata- kata yang bersifat kualitatif dari pada data dalam wujud angkaangka. Oleh karena itu data yang diperoleh secara kualitatif, maka akan dianalisis secara induksi dan deduksi. Analisis induksi digunakan untuk menyimpulkan hal-hal yang umum menuju yang khusus dan analisis deduksi menyimpulkan dari hal-hal yang khusus ke hal yang umum.

Menurut Nasution (1988: 129), langkahlangkah penelitian kualitatif adalah reduksi data, display data dan yang terakhir adalah kesimpulan dan verifikasi.

1. Reduksi data diakukan dengan menyeleksi atau melakukan pemilihan data yang relevan dan bermakna serta dapat memfokuskan data pada pemecahan masalah kemudian disederhanakan dan disusun secara sistematis dengan menonjolkan hal-hal yang penting dan pokok untuk mengambil intisari ringkasan hasil temuan. Hasil reduksi data disajikan dalam laporan secara sistematis yang mudah dipahami.

2. Kesimpulan (verifikasi) sebagai hasil penelitian berdasarkan reduksi data dan display data agar kesimpulan tidak menyimpang dari data dan analisis. Verifikasi dimaksudkan agar penilaian tentang kesesuaian data dengan maksud yang terkandung dalam konsep-konsep dasar dalam penelitian tersebut lebih tepat dan obyektif.

\section{HASIL DAN PEMBAHASAN}

Hasil evaluasi pembelajaran dilakukan dalam dua hal yaitu evaluasi formatif (di tengahtengah) dan evaluasi sumatif (di akhir). Pada saat pengamatan, guru kelas melakukan evaluasi formatif dengan tanya jawab mengenai materi yang diampaikan pada saat penyampaian materi pembelajaran. Sedangkan evaluasi sumatif dilakukan secara bersamaan dengan kelas lain pada saat ulangan semester. Hasil olahan data sekolah SMPN 1 Bayan adalah sebagai berikut:

Tabel 4.1 Hasil Rekapitulasi Frekuensi

\begin{tabular}{|c|c|c|c|}
\hline No & $\begin{array}{c}\text { Jawaban } \\
\text { Responden }\end{array}$ & Frekuensi & Persentase \\
\hline 1 & SS & 2 & $66 \%$ \\
\hline 2 & S & 1 & $33 \%$ \\
\hline 3 & KK & 0 & $0 \%$ \\
\hline 4 & TP & 0 & $0 \%$ \\
\hline
\end{tabular}

Dapat dilihat dari tabel di atas bahwa responden yang menyatakan sangat sering sebanyak 2 orang ( $66 \%$ ), Sementara yang menyatakan sering sebanyak 1 orang ( $33 \%$ ), yang menyatakan kadang kadang sebanyak Nol. Sementara itu yang menyatakan tidak pernah sebanyak Nol.

Berdasarkan data di atas jawaban responden terbanyak yaitu 2 orang (66\%). Dari 3 responden menjawab sangat sering.

\section{Diagram Hasil rekapitulasi Frekuensi}

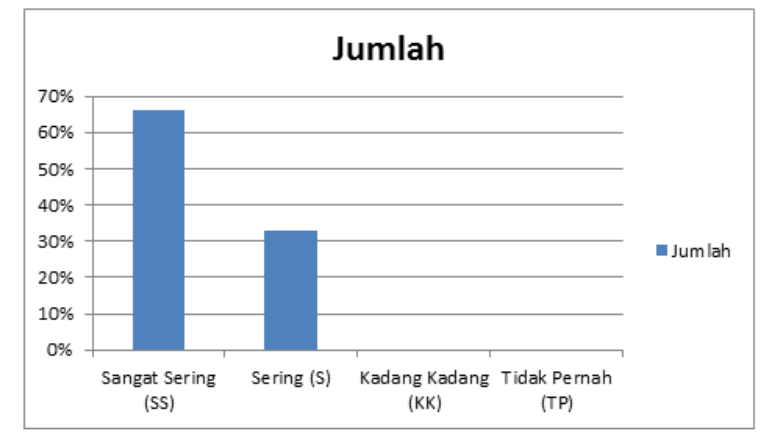

Hasil dari persentase tersebut dengan hasil yang tertinggi yaitu 2 yang menyatakan sangat sering degan hasil $66 \%$ kedua skor 1 yang menyatakan setuju dengan hasil 33\%, ketiga skor menyatakan kadang kadang dengan hasil $0 \%$, keepat skor menyatakan tidak pernah dengan hasil $0 \%$, berdasarkan keterangan diatas keterlaksanaan pembelajaran penjaskes di sekolah SMPN 1 Bayan menyatakan sangat sering.

Tabel 4.2 Hasil Rekapitulasi 
Terakreditasi Peringkat 4 (No. SK: 36/E/KPT/2019)

\begin{tabular}{|c|c|c|c|}
\hline No & $\begin{array}{l}\text { Jawaban } \\
\text { Responden }\end{array}$ & Frekuensi & Persentase \\
\hline 1 & SS & 1 & $33 \%$ \\
\hline 2 & S & 1 & $33 \%$ \\
\hline 3 & KK & 1 & $33 \%$ \\
\hline 4 & TP & 0 & $0 \%$ \\
\hline
\end{tabular}

Sumber: Hasil olahan data SMPN 2 Bayan

Dapat dilihat dari tabel di atas bahwa responden yang menyatakan sangat sering sebanyak 1 orang (33\%), Sementara yang menyatakan sering sebanyak 1 orang ( $33 \%$ ), yang menyatakan kadang kadang sebanyak 1 orang (33\%). Sementara itu yang menyatakan tidak pernah sebanyak Nol.

\section{Diagram Hasil Rekapitulasi Frekuensi}

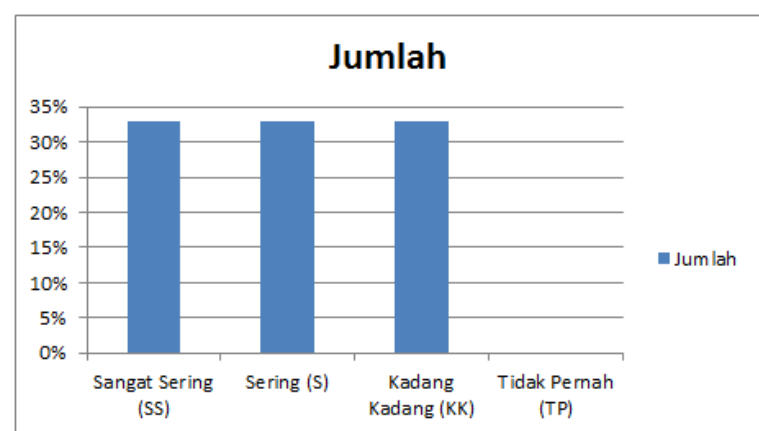

Hasil dari persentase diatas dengan hasil masing masing yang menyatakan sangat sering degan hasil 33\% kedua skor 1 yang menyatakan setuju dengan hasil 33\% , ketiga skor menyatakan kadang kadang dengan hasil 33\%, keepat skor menyatakan tidak pernah dengan hasil Nol. Berdasarkan keterangan diatas keterlaksanaan pembelajaran penjaskes di sekolah SMPN 2 Bayan menyatakan sering.

Tabel 4.3 Hasil Rekapitulasi

\begin{tabular}{|c|c|c|c|}
\hline No & $\begin{array}{l}\text { Jawaban } \\
\text { Responden }\end{array}$ & Frekuensi & Persentase \\
\hline 1 & SS & 1 & $33 \%$ \\
\hline 2 & S & 2 & $66 \%$ \\
\hline 3 & KK & 0 & $0 \%$ \\
\hline 4 & TP & 0 & $0 \%$ \\
\hline
\end{tabular}

Sumber; Hasil olah data di SMPN 3 Bayan

Dapat dilihat dari tabel di atas bahwa responden yang menyatakan sangat sering sebanyak 1 orang ( $66 \%)$, Sementara yang menyatakan sering sebanyak 2 orang ( $66 \%$ ), yang menyatakan kadang kadang sebanyak Nol. Sementara itu yang menyatakan tidak pernah sebanyak Nol.
Berdasarkan data di atas jawaban responden terbanyak yaitu 2 orang (66\%). Dari 3 responden menjawab sering.

\section{Diagram Hasil Rekapitulasi Frekuensi}

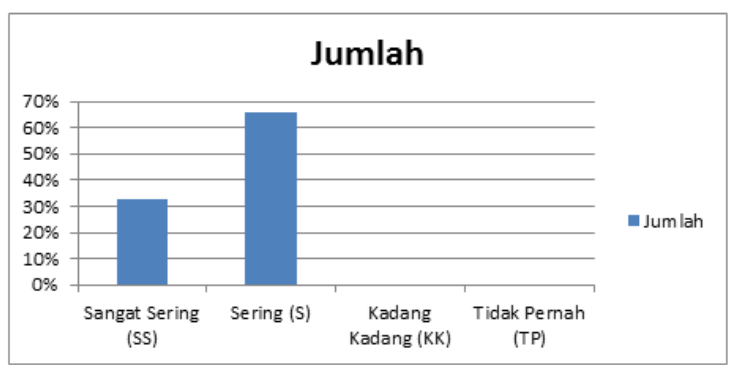

Hasil dari persentase diatas dengan hasil responden yang menyatakan sangat sering degan hasil 33\% kedua skor 1 yang menyatakan sering dengan hasil 66\% , ketiga skor menyatakan kadang kadang dengan hasil 0\%, keepat skor menyatakan tidak pernah dengan hasil Nol. Berdasarkan keterangan diatas keterlaksanaan pembelajaran penjaskes di sekolah SMPN 3 Bayan menyatakan sering.

Tabel 4.4Hasil Rekapitulasi

\begin{tabular}{|c|c|c|c|}
\hline No & $\begin{array}{l}\text { Jawaban } \\
\text { Responden }\end{array}$ & Frekuensi & Persentase \\
\hline 1 & SS & 2 & $66 \%$ \\
\hline 2 & S & 1 & $33 \%$ \\
\hline 3 & KK & 0 & $0 \%$ \\
\hline 4 & TP & 0 & $0 \%$ \\
\hline
\end{tabular}

Sumber: Hasil olah data di SMPN 3 Bayan

Dapat dilihat dari tabel di atas bahwa responden yang menyatakan sangat sering sebanyak 2 orang ( $66 \%)$, Sementara yang menyatakan sering sebanyak 1 orang (33\%), yang menyatakan kadang kadang sebanyak Nol. Sementara itu yang menyatakan tidak pernah sebanyak Nol.

Berdasarkan data di atas jawaban responden terbanyak yaitu 2 orang (66\%). Dari 3 responden menjawab sangat sering.

Diagram Hasil Rekapitulasi Frekuensi

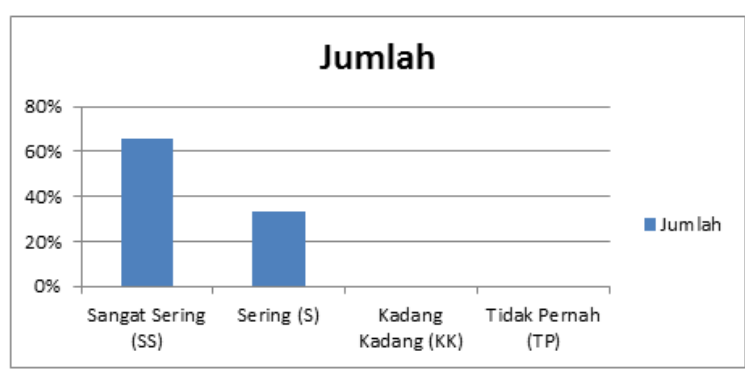


Hasil dari persentase tersebut dengan hasil yang tertinggi yaitu 2 yang menyatakan sangat sering degan hasil 66\% kedua skor 1 yang menyatakan setuju dengan hasil 33\%, ketiga skor menyatakan kadang kadang dengan hasil $0 \%$, keepat skor menyatakan tidak pernah dengan hasil $0 \%$, berdasarkan keterangan diatas keterlaksanaan pembelajaran penjaskes di sekolah SMPN 4 Bayan menyatakan sangat sering.

\section{Pembahasan}

Penelitian ini bertujuan untuk mengetahui bagaiamana keterlaksanaan pembelajaran penjaskes di SMPN Sekecamatan Bayan Kabupaten Lombok Utara. sehingga sangat perlu sebagai peneliti untuk memaparkan dan mendeskripsikan keseluruhan dari hasil jawaban terhadap angket yang ditanggapi oleh para guru olahraga.

Sesuai dengan tujuan penelitian yaitu untuk mengetahui bagamana keterlaksanaan pembelajaran penjaskes di SMPN Sekecamatan Bayan Kabupaten Lombok Utara, maka disini peneliti mencoba memaparkan hasil dari penelitian tersebut dengan mendeskripsikan keterlaksanaan pembelajaran penjaskes melalui pembahasan setiap butir soal/pertanyaan/peryataan sehingga nantinya akan diketahui di butir pemyataan yang mana para guru mengalami kesulitan dalam memahami kesulitan pada saat pengajar, Terdapat 22 peryataan yang diberikan kepada para guru penjaskes, deskripsinya sebagai berikut:

1. Peryataan nomor 1 merupakan pemyataan SS yanmana persentase responden yang menjawab sangat sering berjumlah $66 \%$.

2. Pemyataan nomor 2 merupakan pemyataan SS yang mana persentase responden yang menjawab $\mathrm{SS}$ berjumlah $33 \%$.

3. Pemyataan nomor 3 merupakan pemyataan SS yang mana persentase responden yang menjawab benar berjumlah $66 \%$.

4. Pemyataan nomor 4 merupakan pemyataan SS yang mana persentase responden yang menjawab benar berjumlah $66 \%$.
5. Pemyataan nomor 5 merupakan pemyataan SS yang mana persentase responden yang menjawab SS berjumlah $66 \%$.

6. Pemyataan nomor 6 merupakan pemyataan SS yang mana persentase responden yang menjawab SS berjumlah $66 \%$.

7. Pemyataan nomor 7 merupakan pemyataan SS yang mana persentase responden yang menjawab SS berjumlah $66 \%$.

8. Pemyataan nomor 8 merupakan pemyataan $\mathrm{S}$ yang mana persentase responden yang menjawab $\mathrm{S}$ berjumlah $33 \%$.

9. Pemyataan nomor 9 merupakan pemyataan TP yang mana persentase responden yang menjawab TP berjumlah $0 \%$.

10. Pemyataan nomor 10 merupakan pemyataan SS yang mana persentase responden yang menjawab SS berjumlah $66 \%$.

11.Peryataan no 11 merupakan peryataan SS yanag mana persentase responden yang menjawab SS 66\%

12. Pemyataan nomor 12 merupakan pemyataan SS yang mana persentase responden yang menjawab SS berjumlah $66 \%$.

13. Pemyataan nomor 13 merupakan pemyataan SS yang mana persentase responden yang menjawab SS berjumlah $66 \%$.

14. Pemyataan nomor 14 merupakan pemyataan SS yang mana persentase responden yang menjawab SS berjumlah $66 \%$.

15. Pemyataan nomor 15 merupakan pemyataan SS yang mana persentase responden yang menjawab SS berjumlah $66 \%$.

16. Pemyataan nomor 16 merupakan pemyataan SS yang mana persentase responden yang menjawab SS berjumlah $66 \%$.

17. Pemyataan nomor 17 merupakan pemyataan SS yang mana persentase responden yang menjawab SS berjumlah $66 \%$.

18. Pemyataan nomor 18 merupakan pemyataan SS yang mana persentase responden yang menjawab SS berjumlah $66 \%$.

19. Pemyataan nomor 19 merupakan pemyataan SS yang mana persentase responden yang menjawab SS berjumlah $66 \%$.

20. Pemyataan nomor 20 merupakan pemyataan SS yang mana persentase responden yang menjawab SS berjumlah $66 \%$.

21. Pemyataan nomor 21 merupakan pemyataan $S$ yang mana persentase responden yang menjawab $\mathrm{S}$ berjumlah $33 \%$.

22. $\mathrm{S}$ yang mana persentase responden yang menjawab $\mathrm{S}$ berjumlah $33 \%$. 
Dari keseluruhan pertanyaan di atas dapat diketahui bahwa terdapat sebagian besar guru penjaskes kesulitan dalam melaksanakan mengajar dengan turunan dari definisi terkait yang terdapat pada pertanyaan nomor 9 .

Kemampuan mengevaluasi kegiatan pembelajaran, kemampuan guru dikatakan kurang sesuai dengan pedoman yang ada. Pasalnya guru tidak memberikan program remidial kepada siswa yang dirasa kurang menguasai pembelajaran. Bagi guru di SMPN Sekecamatan bayan tidak ada nilai jelek bagi mata pelajaran pembelajaran pendidikan jasmani olahraga dan kesehatan. Nilai yang diberikan kepada siswa untuk pembelajaran praktek berkisar antara 80 sampai 90 .

Keadaan tersebut terjadi karena guru menganggap pembelajaran pendidikan jasmani olahraga dan kesehatan adalah pelajaran yang mudah dan semua siswa bisa melakukan praktek pembelajaran pendidikan jasmani olahraga dan kesehatan dengan baik. Padahal berdasarkan pengamatan dilapangan, masih banyak siswa yang kurang sesuai dalam melakukan praktek pembelajaran pendidikan jasmani olahraga dan kesehatan. Hal ini dikarenakan kurangnya pemahaman guru tentang teori pembelajaran pendidikan jasmani olahraga dan kesehatan.

\section{SIMPULAN}

Setelah mendapatkan hasil dari penelitian tentang bagaimana keterlaksanaan pembelajaran penjaskes di SMPN Sekecamatan Kabupaten Lombok Utara Tahun Pengajaran 2021, maka peneliti dapat menyimpulkan hasil dari penelitian tersebut sebagai berikut:

1. Pemahaman para guru penjaskes khususnya pada kasus keterlakasanaan pembelajaran penjaskes masuk dalam kategori baik dengan persentase $66 \% \quad 3$ guru penjas dari keseluruhan pelatih (12 guru) yang diambil sebagai sampel, 12\% (12 guru) masuk dalam kategori cukup baik.

2. Hal ini dilihat dari dua segi yaitu keterlaksanaan pembelajaran pendidikan jasmani sekolah serta sarana dan prasarana pendidikan jasmani. Dalam pelaksanaan pembelajaran pendidikan jasmani olahraga dan kesehatan terdapat tiga kompetensi pokok guru yaitu perencanaan, pelaksanaan, dan evaluasi. guru kelas hanya mempunyai kompetensi dalam perencanaan. Sedangkan kompetensi guru yang lain yaitu dalam pelaksanakan dan evaluasi pendidikan jasmani, berjalan dengan baik.

3. Apabila dilihat dari segi sarana dan prasarana, di 4 sekolah tersebut masih cukup lengkap. Hal ini menjadi tantangan tersendiri sebagai seorang pengajar harus memikirkan bagaimana cara memodifikasi sehingga siswa senang dalam belajar pendidikan jasmani olahraga dan kesehatan.

\section{Saran}

Ada beberapa saran yang perlu disampaikan sehubungan dengan hasil penelitian ini, antara lain:

1. Agar para para guru penjaskes berusaha untuk lebih baik lagi dalam mengajar pendidikan jasmani, sehingga dalam mengajar mereka dapat merancang materi ajar yang pas untuk disampaikan ke siswa.

2. Agar para guru penjaskes lebih mendalami terkait kemampuan dalam mengajar pendidikan olaharaga. Ini penting diutarakan oleh peneliti karena guru penjas yang hebat itu guru yang bisa menguasai materi tentang pendidikan jamani dan olahraga.

\section{DAFTAR PUSTAKA}

Abdul Kadir Ateng. 1989. Penganter Asas-asas dan Landasan Pendidikan Jasmani Olahraga. Jakarta : FPOK IKIP Jakarta.

Agus S, Surobroto. 2004. Diktat Mata Kuliah Teknologi Pembelajaran Pendidikan Jasmani. FIK : UNY

Agus, Mahendra. 2003. Falsafah Pembelajaran pendidikan jasmani olahraga dan kesehatan. Jakarta : Direktorat Pendidikan Luar Biasa.

B. Suryosubroto. 1997. Proses Belajar Mengajar Di Sekolah. Jakarta.

Eri Akhid, Hermawan. 2001. Pelaksanaan Pembelajaran pendidikan jasmani olahraga dan kesehatan di Sekolah Dasar Se-Kabupaten Kulon Progo. Yogyakarta : FIK Universitas Negeri Yogyakarta. 
Hamzah B. Uno. 2008. 2011. Profesi Kependidikan. Jakarta: Bumi Aksara.

Hamzah Uno 2008 : 2 Hakekat Perencanaan dan Rancangan Pembelajaran Siswa

Hartono. dkk , 2013 : 2. Pengerian Pendidikan Jasmani Olahraga dan Kesehatan.

Hudarta, 2011 : $18 . \quad$ Pengertian pendidikan jasmani Olahraga dan Kesehatan.

Huesdarta \& Yudha M. Saputra. 2000. Belajar dan Pembelajaran. Jakarta: Erlangga.

Lexy J. Meleong 1994 prosedur Teknik Pengumpulan Data.

Martin, Yamin. 2005. Strategi Pembelajaran Berbasis Kompetensi. Ciputat: Gaung Pesada Press.

Nana Sudjana. 2002. Penilaian Hasil Proses Belajar Mengajar. Bandung: Remaja Rosdakarya.

Ratal Wirjasantosa. 1984. Supervisi Pendidikan Olahraga. Jakarta : Universitas Indonesia.

Rusli Lutan. 2001. Asas-Asas Pembelajaran pendidikan jasmani olahraga dan kesehatan. Dirjen Olahraga : Depdiknas.

Soepartopo. 2000. Sarana dan Prasarana Pendidikan Olahraga.

Suharsimi Arikunto. 2002. Prosedur Penelitian Suatu Pendekatan Praktik. Syaiful Sagala. 2006. Konsep dan Makna Pembelajaran. Bandung.

Suharsimi, Arikunto. 2002. Metodologi Penelitian. Jakarta.

Taqwim et al, 2020 Pelaksanaan Pembelajaran Guru Pendidikan Jasmani

Uzer Usman. 2006. Menjadi Guru Profesional. Remaja Rosdakarya : Bandung.

Wahit Iqbal, Mubarak, dkk. 2012. Promosi Kesehatan : Sebuah Pengantar Proses Belajar Mengajar dalam Pendidikan. 